\title{
Rola doszklistkowych steroidów we współczesnym leczeniu cukrzycowego obrzęku plamki
}

\author{
The role of intravitreal steroid injections in contemporary treatment \\ of diabetic macular edema
}

\author{
Sławomir Teper', Agnieszka Kubicka-Trząska², Anna Matysik-Woźniak³ , Edward Wylęgała', \\ Jerzy Mackiewicz', Katarzyna Michalska-Małecka ${ }^{5}$, Marek Rękas ${ }^{6}$, Robert Rejdak ${ }^{3}$ \\ 'Katedra i Oddział Kliniczny Okulistyki Wydział Lekarski z Pododdziałem Lekarsko-Dentystycznym w Zabrzu, Śląski Uniwersytet Medyczny w Katowicach \\ ${ }^{2}$ Klinika Okulistyki i Onkologii Okulistycznej Katedry Okulistyki, Wydział Lekarski, Uniwersytet Jagielloński Collegium Medicum w Krakowie \\ ${ }^{3}$ Klinika Okulistyki Ogólnej Uniwersytetu Medycznego w Lublinie \\ ${ }^{4}$ Klinika Chirurgii Siatkówki i Ciała Szklistego Uniwersytetu Medycznego w Lublinie \\ ${ }^{5} / I$ Klinika Okulistyki Dorosłych, Uniwersyteckie Centrum Okulistyki i Onkologii w Katowicach \\ ${ }^{6}$ Klinika Okulistyki Wojskowego Instytutu Medycznego w Warszawie
}

\section{STRESZCZENIE}

Powikłania cukrzycy są jednym z najczęstszych i najpoważniejszych problemów we współczesnej okulistyce. W pracy przedstawiono dane epidemiologiczne i zasady leczenia retnopatii cukrzycowej i cukrzycowego obrzęku plamki. Szczególną uwagę zwrócono na rolę iniekcji doszklistkowych, w tym steroidów, które w niektórych przypadkach mogą być alternatywą dla inhibitorów naczyniowo-śrdódbłonkowego czynnika wzrostu (anty-VEGF). Zdaniem grupy ekspertów konieczne jest stworzenie programu lekowego obejmującego leczenie cukrzycowego obrzęku plamki, który istotnie poprawi dostęp do nowoczesnej terapii dużej grupie chorych. W programie lekowym lekiem pierwszego rzutu powinien być anty-VEGF z możliwością zmiany na doszklistkowy implant deksametazonu, w przypadku braku odpowiedzi na leczenie lub istnienia przeciwskazań do terapii anty-VEGF. Należy stworzyć precyzyjne kryteria kwalifikacji do programu, zdefiniować brak odpowiedzi na leczenie oraz określić wskazania do zmiany leku.

SŁOWA KLUCZOWE: cukrzyca; cukrzycowy obrzęk plamki; iniekcje doszklistkowe; deksametazon

Ophthalmol J 2018; Vol. 3, No. 2, 37-46

\section{ABSTRACT}

Complications of diabetes are one of the most common and serious problems in contemporary ophthalmology. The paper presents epidemiological data and principles of treatment of diabetic retinopathy and diabetic macular edema. Particular attention has been paid to the role of intravitreal injections, including steroid injections, which in some cases may be an alternative to anti-VEGF therapy. According to the group of experts, it is necessary to develop a drug program for the treatment of diabetic macular edema, which will significantly improve access to modern treatment for a large group of patients. In the drug program, the first-line treatment should be a VEGF inhibitor, with the possibility of switching to the intravitreal dexamethasone implant in patients who do not respond to treatment or have contraindications for anti-VEGF therapy. Precise qualification criteria for the program should be determined, the lack of response to treatment defined and indications for drug change specified.

KEY WORDS: diabetes; diabetic macular edema; intravitreal injections; dexamethasone

Ophthalmol J 2018; Vol. 3, No. 2, 37-46 


\section{CUKRZYCA I JEJ POWIKŁANIA OCZNE — DANE EPIDEMIOLOGICZNE}

Cukrzyca stanowi ogromny problem społeczny i ekonomiczny, a zapadalność na nią stale wzrasta. Szacuje się, że w Polsce na cukrzycę choruje ok. 7,6\% dorosłych w wieku 20-79 lat [1]. Szczególnym problemem osób chorych na cukrzycę są zaburzenia widzenia, często uniemożliwiające pracę zawodową, prowadzenie pojazdów mechanicznych czy samodzielne funkcjonowanie. Oczne powikłania cukrzycy są główną przyczyną znacznego pogorszenia widzenia w grupie pacjentów poniżej 50. rż. [1]. Obejmują one retinopatię cukrzycową, cukrzycowy obrzęk plamki (DME, diabetic macular edema), trakcyjne odwarstwienie siatkówki, jaskrę neowaskularną. Największym problemem jest DME, który występuje (wg różnych źródeł) u około 7-14\% ogółu chorych na cukrzycę i nieleczony może spowodować trwałe obniżenie ostrości wzroku [1]. Według Raportu Instytutu Ochrony Zdrowia Choroby oczu - problem zdrowotny, spoteczny oraz wyzwanie cywilizacyjne $w$ obliczu starzenia sie populacji na DME cierpi w Polsce około 160 tysięcy osób (2018 r.), przy czym szacuje się, liczba ta zwiększy się do około 200 tysięcy w $2030 \mathrm{r}$. [1]. Szacuje się, że $40 \%$ chorych na DME ma mniej niż 45 lat [1]. Czas trwania cukrzycy jest najważniejszym czynnikiem ryzyka DME i retinopatii proliferacyjnej. Po 25 latach trwania cukrzycy typu 1 DME występuje u ok. $29 \%$ chorych. W cukrzycy typu 2 po 30 latach trwania choroby DME pojawia się u $28 \%$ leczonych insuliną oraz u $14 \%$ leczonych doustnymi lekami hipoglikemizującymi.

Prawidłowe postępowanie w przypadku ocznych powikłań cukrzycy powinno obejmować zarówno leczenie choroby podstawowej przez diabetologa, jak i terapię okulistyczną. Ważne, by chorzy na cukrzycę byli poddawani regularnym badaniom okulistycznym w celu wykrycia zaburzeń wymagających leczenia w najwcześniejszej fazie (rola telemedycyny). We wczesnej fazie powikłań leczenie jest najbardziej skuteczne i efektywne ekonomicznie. Odpowiednio wcześnie wykryte powikłania okulistyczne mogą być w większości przypadków skutecznie leczone, a tym samym widzenie zostaje zachowane. Obliczono, że niedostateczne leczenie może być droższe dla gospodarki polskiej niż koszty prawidłowo prowadzonej terapii. Zgodnie z szacunkami koszty pośrednie (tzn. wartość niewytworzonego PKB) DME w Polsce w 2016 r. wyniosły 1,092 mld złotych $(0,059 \%$ PKB) i były 12-krotnie wyższe niż koszty bezpośrednie, które obliczono na $92 \mathrm{mln}$ złotych. Dla porównania — koszty pośrednie zwyrodnienia plamki związanego z wiekiem (AMD, age-related macular degeneration) $\mathrm{w}$ tym samym czasie wyniosły $748 \mathrm{mln}$ złotych $(0,040 \%$ PKB) [2]. Wyższe koszty DME wynikają z faktu, że na to schorzenie cierpi więcej osób będących w wieku produkcyjnym.

Niestety w Polsce leczenie DME jest niewystarczająco uregulowane. Brakuje zwłaszcza programu lekowego analogicznego do tego, którym już zostali objęci pacjenci z AMD i który stał się dużym sukcesem terapeutycznym w skali kraju.

\section{WYTYCZNE LECZENIA DME WEDŁUG NAJWAŻNIEJSZYCH TOWARZYSTW OKULISTYCZNYCH}

Poniżej przedstawiono najnowsze zalecenia dotyczące leczenia cukrzycowego obrzęku plamki na podstawie wytycznych Polskiego Towarzystwa Okulistyczne (PTO), The European Society of Retina Specialists (EURETINA) [3] i Amerykańskiej Akademii Okulistycznej [4].

W przypadku klinicznie istotnego obrzęku plamki z zajęciem dołka (zwłaszcza z pogorszeniem ostrości wzroku, obrzęku rozlanego):

— iniekcje doszklistkowe leków anty-VEGF są leczeniem pierwszego rzutu (first line therapy), które powinno być rozpoczęte jak najwcześniej. Przy czym aflibercept zalecany dla pacjentów z gorszą wyjściową ostrością wzroku, to znaczy jeżeli początkowa ostrość wzroku < 69 liter na tablicach ETDRS (ok. 0,5 na tablicach Snellena). W przypadku lepszej początkowej ostrości wzroku wszystkie leki anty-VEGF działaja podobnie w okresie pierwszych 2 lat leczenia. Jednakże należy pamiętać, że stanowisko oparto na wyniku badania Protocol T, w którym stosowano ranibizumab w dawce mniejszej $(0,3 \mathrm{mg})$ niż zarejestrowana w Unii Europejskiej $(0,5 \mathrm{mg})$;

- przy braku odpowiedzi na terapię lekami anty -VEGF (po 3-6 iniekcjach, w zależności od odpowiedzi pacjenta) rozważyć należy doszklistkowe iniekcje steroidów. Preferowanym lekiem jest deksametazon (Ozurdex), a w dalszej kolejności fluocinolon (Iluvien) oraz triamcynolon. Doszklistkowe iniekcje steroidów mogą być lekami pierwszego wyboru u pacjentów z przeciwskazaniami do iniekcji anty-VEGF (np. epizody sercowo-naczyniowe) oraz u pacjentów, którzy nie mogą często zgłaszać się na iniekcje [ale konieczna jest kontrola ciśnienia wewnątrzgałkowego (IOP, intraocular pressure po wykonaniu procedury)]. $\mathrm{Z}$ uwagi na możliwość zmętnienia soczewki, preferowani są pacjenci pseudofakijni [3]; 
- laseroterapia nie ma przewagi nad farmakoterapią. Według rekomendacji EURETINA laseroterapia nie jest już standardem $\mathrm{w}$ terapii DME, a względy ekonomiczne i organizacyjne (mniejsze koszty niż iniekcje, mniej wizyt) nie powinny uzasadniać jej stosowania [3]. Należy poinformować pacjenta o możliwości wystąpienia mroczków. Obecnie laseroterapia ma ograniczone wskazania. Można rozważyć jej wykonanie w przypadkach obrzęku naczyniopochodnego, który charakteryzuje się obecnością ogniskowo zgrupowanych mikroaneuryzmatów (MA, microaneurysm) i przeciekiem z kapilar. Ponadto, gdy centralna grubość siatkówki (CRT, central retinal thickness) jest mniejsza $<300 \mu \mathrm{m}$, utrzymuje się przyleganie szklistkowo siatkówkowe (w takich przypadkach skuteczność lasera i iniekcji anty-VEGF jest podobna) [3]. Według Amerykańskiej Akademii Okulistycznej laseroterapię należy przeprowadzać co najmniej poza obszarem $500 \mu \mathrm{m}$ od dołka. Zaleca się wykonywanie mniej intensywnych i rzadziej rozmieszczonych ognisk, skierowanych na MA [4]. Laser podprogowy typu grid może być pomocny we wczesnym etapie rozlanego DME w oczach z dobrą ostrością wzroku jako tańsza niż iniekcje opcja terapeutyczna [3];

- witrektomia przez pars plana (PPV, pars plana vitrectomy) jest rekomendowana $\mathrm{w}$ przypadku trakcji szklistkowo-plamkowych [3]. Może być rozważona przy braku odpowiedzi na leczenie iniekcjami i bez tylnego odłączenia ciała szklistego (PVD, posterior vitreous detachment) (choć nie zawsze poprawie anatomicznej uzyskanej w wyniku PPV towarzyszy równoległa poprawa funkcji).

\section{ROLA DOSZKLISTKOWYCH INIEKCJI STEROIDÓW: OZURDEX — DANE Z CODZIENNEJ PRAKTYKI KLINICZNEJ NA ŚWIECIE}

Rola iniekcji anty-VEGF jako leków pierwszego rzutu w leczeniu DME jest bezsporna. Tym niemniej istnieją także ważne przesłanki do stosowania doszklistkowych steroidów. W literaturze znajdują się publikacje przedstawiające wyniki obserwacji chorych z DME leczonych w ramach codziennej praktyki klinicznej doszklistkowym implantem deksametazonu - preparatem Ozurdex (DEX 0,7 mg) [5-11]. Nierzadko zarówno zasady tych badań, jak i schematy leczenia odbiegają od tych, jakie obowiązują w protokołach randomizo- wanych badań klinicznych. Badaniem należącym do tzw. real-life studies, obejmującym największą liczbę chorych (89 chorych, 128 oczu), z najdłuższym okresem obserwacji wynoszącym 36 miesięcy, było badanie RELDEX [12]. W badanej grupie chorych czas trwania DME wynosił średnio 24,7 miesiąca, a w $26,6 \%$ przypadków leczenie z zastosowaniem implantu doszklistkowego DEX 0,7 mg było pierwszą zastosowaną terapią. Przyczyną włączenia DEX $0,7 \mathrm{mg}$ jako leku pierwszego rzutu u tych chorych był obciążający wywiad ogólny (stan po zawale serca, wysokie nieuregulowane ciśnienie tętnicze) oraz brak zgody chorego na comiesięczne wizyty kontrolne związane $\mathrm{z}$ terapią czynnikiem anty-VEGF. Średni odstęp czasu między reiniekcjami implantu DEX 0,7 mg wynosił 7,3 miesiąca, a częstość iniekcji doszklistkowych malała wraz z czasem trwania obserwacji; średnio w okresie trwania badania podano 3,6 iniekcji DEX 0,7 mg. W żadnym przypadku nie stwierdzono wskazań do wykonania uzupełniającej laserokoagulacji siatkówki. Wzrost IOP odnotowano u około $1 / 3$ chorych, w 2 przypadkach przerwano terapię z powodu podwyższonego IOP niereagującego na leczenie miejscowe. W żadnym przypadku nie wykonano zabiegu przetokowego. Materiał obejmował $45 \%$ oczu fakijnych, w których już w chwili kwalifikacji do leczenia stwierdzono początki zaćmy. Aż $70 \%$ operacji zaćmy przeprowadzono w pierwszym roku obserwacji, przy czym w żadnym przypadku nie odnotowano progresji DME po przeprowadzonym zabiegu. U wszystkich chorych miesiąc przed planowanym zabiegiem fakoemulsyfikacji zastosowano doszklistkową iniekcję DEX 0,7 mg. Odległe obserwacje nie wykazały negatywnego wpływu progresji lub rozwoju zaćmy de novo na ostateczną najlepszą skorygowaną ostrość wzroku (BCVA, best corrected visual acuity). Korzyści uzyskane $\mathrm{w}$ wyniku zastosowanego leczenia z zastosowaniem DEX 0,7 mg były porównywalne w grupie oczu fakijnych i pseudofakijnych. Autorzy w ciągu całego okresu 3-letniej obserwacji odnotowywali stopniową i powolną poprawę BCVA w badanej grupie chorych.

Celem kolejnego real-life study, w którym wzięło udział 14 ośrodków z całego świata, było porównanie wyników leczenia doszklistkowymi iniekcjami czynnika anty-VEGF i DEX $0,7 \mathrm{mg}$ u chorych z DME opornym na leczenie doszklistkowymi iniekcjami anty-VEGF w codziennej praktyce klinicznej [13]. W badaniu wzięło udział 105 chorych (110 oczu), a czas obserwacji wynosił 12 miesięcy. Wszystkim chorym, którzy wcześniej nie byli leczeni z powodu 
DME, podano w odstępach comiesięcznych 3-4 doszklistkowe iniekcje czynnika anty-VEGF. Następnie przeprowadzano badanie kontrolne: w przypadku stwierdzenia braku lub słabej odpowiedzi na leczenie antyangiogenne na podstawie wyniku BCVA (zmiana $\mathrm{o} \leq 5$ liter) oraz optycznej koherentnej tomografii dna oka (OCT, optical coherence tomography) (zmiana CRT o $\leq 20 \%$ ) chorego kwalifikowano do terapii z zastosowaniem DEX 0,7 mg. W analizowanym materiale odsetek osób, które nie zareagowały pozytywnie na terapię anty-VEGF (tzw. non-responders), wynosił $34,5 \%$. Gonzalez i wsp. w analizie danych badania Protokół I wykazali, że odsetek chorych z DME niereagujących na doszklistkowe iniekcje czynnika anty -VEGF może być jeszcze większy i może sięgać nawet 39,7\% [14]. W badaniu Busch i wsp. ostatecznie wykazano, iż u chorych z DME, u których leczenie anty -VEGF było nieskuteczne, wczesna zmiana terapii na DEX 0,7 mg (po fazie nasycającej leczenia antyangiogennego) powoduje osiągnięcie lepszej ostatecznej BCVA oraz sprzyja uzyskaniu większej poprawy anatomicznej plamki ocenianą w OCT w porównaniu $\mathrm{z}$ chorymi leczonymi tylko anty-VEGF w okresie rocznej obserwacji [14].

W metaanalizie obejmującej 3859 chorych z 15 badań oceniano skuteczność DEX 0,7 mg w leczeniu DME opornego na terapię anty-VEGF [13]. Analiza uzyskanych wyników wykazała, iż terapia z zastosowaniem DEX 0,7 mg poprawia w sposób istotny statystycznie BCVA, nawet $\mathrm{w}$ przypadku chorych, u których nie uzyskano odpowiedzi na leczenie doszklistkowymi iniekcjami czynnika anty-VEGF. Najczęściej opisywanym powikłaniem związanym z leczeniem doszklistkowym implantem DEX 0,7 mg w codziennej praktyce klinicznej był wzrost IOP. Wzrost wartości IOP o $>10 \mathrm{~mm} \mathrm{Hg}$ $\mathrm{w}$ porównaniu $\mathrm{z}$ wartością wyjściową stwierdzono w $19-41,5 \%$ przypadków, wzrost o $\geq 35 \mathrm{~mm}$ $\mathrm{Hg}$ - u 6,6-7,2\% chorych, a odsetek chorych, u których wystąpiła konieczność wykonania zabiegu przetokowego, wynosiła tylko 0,3-0,6\% [7]. Drugim pod względem częstości występowania powikłaniem był rozwój lub progresja zaćmy. Odsetek chorych $\mathrm{z}$ tym powikłaniem był różny i wahał się od $22,2 \%$ do $64,2 \%$ w zależności od czasu trwania badania. W obserwacjach wykazano, że operacja zaćmy poprawiała BCVA w grupie chorych leczonych z zastosowaniem implantu doszklistkowego DEX $0,7 \mathrm{mg}$, a ostateczne wyniki funkcjonalne były porównywalne w oczach fakijnych i pseudofakijnych. Rzadkimi powikłaniami opisanymi u chorych leczonych z zastosowaniem implantu DEX 0,7 mg było zapalenie wnętrza gałki ocznej, przy czyn należy podkreślić, iż powikłanie to jest częstsze u chorych leczonych doszklistkowymi steroidami niż preparatami anty-VEGF $(0,13 \%$ vs. $0,019 \%)$. Przedstawiono pojedyncze przypadki reaktywacji wirusowego zapalenia siatkówki - ostrej martwicy siatkówki, wylew krwi do komory ciała szklistego i siatkówki oraz powstanie otworu w plamce w oczach z obecną trakcją szklistkowo-plamkową [14].

Kodjikian i wsp. przeprowadzili porównanie skuteczności leczenia z zastosowaniem doszklistkowych iniekcji czynnika anty-VEGF oraz implantu DEX $0,7 \mathrm{mg}$, dokonując analizy wyników 63 badań obejmujących odpowiednio 6842 i 1703 oczu z DME [15]. Średni okres obserwacji wynosił 15,6 miesiąca w grupie anty-VEGF i 10,3 miesiąca w grupie DEX $0,7 \mathrm{mg}$, a średnia liczba wykonanych doszklistkowych iniekcji wynosiła odpowiednio 5,8 i 1,6. Głównym analizowanym parametrem oceniającym wyniki leczenia była BCVA. Stwierdzono, iż ostateczna BCVA była podobna w obu analizowanych grupach i wynosiła 62 litery w oczach leczonych anty-VEGF oraz 61,2 litery w oczach, które otrzymały implant DEX 0,7 mg. Mimo że w obu leczonych grupach chorych ostateczna ostrość wzroku była porównywalna, należy podkreślić, iż wyjściowa BCVA była niższa w oczach leczonych z zastosowaniem implantu DEX 0,7 mg, co oznacza, iż w tych oczach uzyskano ostatecznie większą poprawę BCVA. W przypadkach leczonych DEX 0,7 mg wykazano istnienie wprost proporcjonalnej zależności między wyjściową a końcową BCVA, tj. im lepsza wyjściowa BCVA, tym większą uzyskiwano poprawę BCVA i tym samym lepszą końcową funkcję leczonego oka, przy czym spostrzeżenie to dotyczyło przede wszystkim chorych wcześniej nieleczonych z powodu DME, u których implant DEX 0,7 mg był pierwszą zastosowaną terapią. Biorąc pod uwagę powyższe obserwacje, autorzy sugerują, że DEX 0,7 mg może być stosowany jako lek pierwszego rzutu w oczach wcześniej nieleczonych z powodu z DME, a także że można go uwzględniać znacznie wcześniej w leczeniu DME jako lek drugiego rzutu. Wśród powikłań miejscowych autorzy najczęściej wymieniają zaćmę (0-50\% przypadków) oraz wzrost IOP (0-29,5\% przypadków). Tylko w jednym przypadku spośród 1703 oczu leczonych z zastosowaniem implantu DEX 0,7 mg zaistniały wskazania do wykonania zabiegu przetokowego. W jednym oku wystąpiło zapalenie wewnątrzgałkowe.

Najważniejsze wnioski wynikające $\mathrm{z}$ real-life studies dotyczących skuteczności i bezpieczeństwa 
stosowania doszklistkowego implantu DEX 0,7 mg u chorych z DME są następujące:

- doszklistkowy implant DEX $0,7 \mathrm{mg}$ jest bezpieczną i skuteczną metodą leczenia przewlekłego i opornego na inne metody terapii DME;

- leczenie z zastosowaniem implantu DEX 0,7 mg prowadzi do istotnej poprawy BCVA, przy czym im lepsza jest wyjściowa BCVA, tym większa poprawa $\mathrm{w}$ zakresie ostatecznej funkcji leczonego oka. Szczególnie istotną poprawę BCVA obserwuje się w oczach wcześniej nieleczonych z powodu DME. W oczach z niską wyjściową BCVA efekty leczenia z zastosowaniem implantu DEX $0,7 \mathrm{mg}$ są również korzystne, a ostateczna BCVA jest lepsza aniżeli w oczach leczonych czynnikiem anty -VEGF. Wyniki funkcjonalne leczenia z zastosowaniem implantu DEX 0,7 mg są porównywalne w oczach fakijnych i pseudofakijnych;

— stosowanie implantu DEX 0,7 mg jako leczenia drugiego rzutu zaleca się u chorych, u których nie uzyskuje się odpowiedzi na terapię anty -VEGF po fazie nasycającej, tj. zazwyczaj po 3-6 iniekcjach anty-VEGF. Biorąc pod uwage wyniki obserwacji z codziennej praktyki klinicznej, niektórzy badacze sugerują, aby rozważyć włączenie implantu DEX 0,7 mg jako terapii pierwszego rzutu, w szczególności w przypadku nieleczonych wcześniej oczu z DME [14]. Ze względu na obserwowaną większą poprawę BCVA, nawet $\mathrm{w}$ przypadku niskiej wyjściowej BCVA w oczach leczonych z zastosowaniem implantu DEX 0,7 mg w porównaniu z leczonymi czynnikiem anty-VEGF, można także rozważyć wcześniejsze doszklistkowe podanie steroidu jeszcze przed zakończeniem fazy nasycającej leczenia czynnikiem anty-VEGF;

— najczęściej obserwowanym powikłaniem związanym z leczeniem doszklistkowym implantem DEX 0,7 mg jest rozwój zaćmy oraz wzrost IOP. Wyniki badań klinicznych wykazały jednak, iż ostateczna BCVA w oczach leczonych z zastosowaniem implantu DEX 0,7 mg jest porównywalna w oczach fakijnych i pseudofakijnych. Wzrost IOP jest natomiast zazwyczaj skutecznie kontrolowany lekami miejscowymi.

\section{LECZENIE DME —ZASADY POSTĘPOWANIA W KONKRETNYCH SYTUACJACH KLINICZNYCH}

Grupa pacjentów z DME jest niejednorodna. Zarówno retinopatia cukrzycowa, jak i sam obrzęk plamki mogą różnić się stopniem zaawansowania, nierzadko są one niewspółmierne do siebie. Dodatkowo tę grupę pacjentów różnicuje wiele towarzyszących zmian morfologicznych i funkcjonalnych, które mogą towarzyszyć retinopatii. Leczenie powinno być zatem spersonalizowane i musi uwzględniać także wiele przeciwwskazań związanych z sytuacją kliniczną osoby chorej. Wśród zmian towarzyszących należy uwzględnić przede wszystkim strukturę złącza szklistkowo-siatkówkowego, obecność, stopień zaawansowania i rodzaj jaskry, zakres i lokalizację niedokrwienia siatkówki, stan ogólny pacjenta itp.

Poniżej przedstawiono podstawowe zasady postępowania $\mathrm{w}$ poszczególnych sytuacjach klinicznych. Obejmują one nie tylko postępowanie lecznicze, ale również wskazaną diagnostykę z badaniami obrazowymi [17]. Wykorzystano podział retinopatii cukrzycowej zgodny z wytycznymi National Eye Institute [18] na:

- retinopatię nieproliferacyjną (NPDR, nonproliferative diabetic retinopathy) — lagodną, umiarkowaną, ciężką;

- retinopatię proliferacyjną (PDR, proliferative diabetic retinopathy).

Autorzy sugerują stosowanie leków zgodnie z zaleceniami z charakterystyki produktu leczniczego dla poszczególnych preparatów. Skuteczność laseroterapii mikropulsowej w cukrzycowym obrzęku plamki jest ograniczona - można ją stosować, gdy obrzęk nie przekracza ok. $400 \mu \mathrm{m}$. Ze względu na nieinwazyjny charakter można ją dodać do innych opcji terapeutycznych, ale wobec braku dostępności lub większego zaawansowania choroby nie należy zwlekać z kolejnymi wymienionymi metodami [3, 4, 19-28].

Podkreśla się, że każdy pacjent z retinopatią cukrzycową wymaga okresowego wykonania badania OCT plamki oraz obrazowania dna oka po rozszerzeniu źrenicy. W zależności od wskazań stosuje się pozostałe metody diagnostyczne, np. angiografię fluoresceinową (AF).

\section{RETINOPATIA CUKRZYCOWA PRZEDPROLIFERACYJNA BEZ OBRZĘKU PLAMIKI \\ U pacjentów z retinopatią cukrzycowa przedpro- liferacyjną (NPDR) i bez obrzęku plamki (DME) postępowanie zależy od stopnia zaawansowa- nia NDPR: \\ — w postaci początkowej i umiarkowanej — ob- serwacja: \\ - zgodnie z wytycznymi przedstawionymi w dalszej części artykułu,}


- okresy kontroli można zindywidualizować; stężenie hemoglobiny glikowanej $\left(\mathrm{HbA}_{1 \mathrm{c}}\right)$, czas trwania cukrzycy, ciśnienie tętnicze są czynnikami wpływającymi na częstość kolejnych badań [17];

— w postaci zaawansowanej:

- AF (szerokokątna, jeżeli możliwe),

- wybiórcza laseroterapia na dalekim obwodzie siatkówki.

\section{RETINOPATIA CUKRZYCOWA PROLIFERACYJNA BEZ OBRZĘKU PLAMIKI}

U pacjentów z retinopatią cukrzycową proliferacyjną (PDR) bez obrzęku plamki (DME) postępowanie uzależnia się od braku lub występowania krwotoku do ciała szklistego. U chorych:

— bez krwotoku do ciała szklistego:

- fotokoagulacja panretinalna (PRP, panretinal photocoagulation) lub leczenie z zastosowaniem anty-VEGF w zależności od dostępności leków oraz możliwości wykonania laseroterapii (np. niemożność wykonania skutecznej PRP z powodu neuropatii współczulnej — miernego rozszerzania się źrenic). Wyniki najnowszych badań sugerują, że warto rozpocząć od leczenia anty-VEGF,

— z krwotokiem do ciała szklistego:

- powinno dążyć się do wykonania PRP, gdy stanie się to możliwe,

- krwotok pogarszający widzenie uniemożliwiający wykonanie PRP jest wskazaniem do witrektomii PPV w okresie od 1 do 2 miesięcy po wystąpieniu

- jeżeli krwotokowi towarzyszy odwarstwienie siatkówki przedarciowe lub trakcyjne zagrażające plamce, lub neowaskularyzacja kąta/tęczówki - PPV powinna być wykonana w trybie pilnym,

- leczenie z zastosowaniem anty-VEGF podawanymi co miesiąc może przyspieszyć wchłanianie krwotoku, zredukować konieczność wykonania PPV, jeżeli krwotokowi nie towarzyszy odwarstwienie siatkówki.

\section{RETINOPATIA CUKRZYCOWA PRZEDPROLIFERACYJNA Z OBRZĘKIEM PLAMKI POZA DOEKIEM}

U pacjentów z retinopatią cukrzycową przedproliferacyjna (NPDR) z obrzękiem plamki (DME) poza dołkiem postępowanie zależy od nasilenia i obejmuje:
— obserwację — jeżeli występuje niewielki obrzęk z dala od dołka;

— laseroterapię mikropulsową — jeżeli grubość siatkówki nie przekracza $400 \mu \mathrm{m}$;

- laseroterapię klasyczną typu focallgrid zgodnie z OCT plamki i AF.

\section{RETINOPATIA CUKRZYCOWA \\ PRZEDPROLIFERACYJNA Z OBRZĘKIEM PLAMKI I ZAJĘCIEM DOŁKA}

Pełna skorygowana ostrość wzroku (BCVA)

U chorych z retinopatią cukrzycową przedproliferacyjną (NPDR) z obrzękiem plamki (DME) i zajęciem dołka oraz pełną skorygowaną ostrością wzroku (BCVA) zaleca się:

- laseroterapię mikropulsową;

— terapię fibratami.

\section{Skorygowana ostrość wzroku (BCVA) $<1,0 \mathrm{i}>0,5$}

U chorych z retinopatią cukrzycową przedproliferacyjną (NPDR), obrzękiem plamki (DME) i zajęciem dołka oraz skorygowaną ostrością wzroku (BCVA) $<1,0$ i $>0,5$ opcje terapeutyczne obejmują kolejno do rozważenia:

— leczenie z zastosowaniem anty-VEGF;

+/- kolejno:

- laseroterapię mikropulsową plamki — jeżeli grubość siatkówki nie przekracza $400 \mu \mathrm{m}$;

- zastosowanie deksametazonu — w postaci implantu podawanego do ciała szklistego, gdy pomimo 5-6 comiesięcznych iniekcji anty-VEGF nie odnotowano poprawy w zakresie morfologii lub funkcji siatkówki.

\section{Skorygowana ostrość wzroku (BCVA) $<0,5$}

$\mathrm{U}$ chorych z retinopatią cukrzycową przedproliferacyjną (NPDR), obrzękiem plamki (DME) i zajęciem dołka oraz skorygowaną ostrością wzroku $(\mathrm{BCVA})<0,5$ kolejno należy rozważyć leczenie $\mathrm{z}$ zastosowaniem:

— afliberceptu (Eylea);

- ranibizumabu (Lucentis);

- bewacyzumabu (Avastin);

+/- kolejno:

- laseroterapię mikropulsową plamki — jeżeli grubość siatkówki nie przekracza $400 \mu \mathrm{m}$;

— zastosowanie deksametazonu - w postaci implantu podawanego do ciała szklistego, gdy pomimo 5-6 comiesięcznych iniekcji anty-VEGF nie odnotowano poprawy w zakresie morfologii lub funkcji siatkówki. 


\section{ZAAWANSOWANA RETINOPATIA CUKRZYCOWA PRZEDPROLIFERACYJNA LUB RETINOPATIA PROLIFERACYJNA Z OBRZĘKIEM PLAMKI I ZAJĘCIEM DOŁKA}

Skorygowana ostrość wzroku (BCVA) = 1,0

Postać praktycznie niewystępująca. Leczenie podobnie jak powyżej.

\section{Skorygowana ostrość wzroku (BCVA) $<1,0$}

U chorych z zaawansowaną retinopatią cukrzycową przedproliferacyjną (NPDR) lub retinopatią proliferacyjną (PDR) z obrzękiem plamki (DME) i zajęciem dołka oraz skorygowaną ostrością wzroku (BCVA) < 1,0 zaleca się:

— w szczególności terapię $\mathrm{z}$ zastosowaniem anty -VEGF ze względu na ich bezsporny wpływ na potencjalne odwrócenie zaawansowanej retinopatii;

+/- obie poniższe możliwości:

— zastosowanie deksametazonu - w postaci implantu podawanego do ciała szklistego, gdy pomimo 5-6 comiesięcznych iniekcji anty-VEGF nie odnotowano poprawy w zakresie morfologii lub funkcji siatkówki;

— klasyczną laseroterapię obwodu siatkówki i ewentualnie typu ogniskowego w plamce, gdy iniekcje do ciała szklistego nie pozwoliły na poprawę w zakresie morfologii i/lub funkcji siatkówki.

\section{RETINOPATIA CUKRZYCOWA}

PRZEDPROLIFERACYJNA, ZAAWANSOWANA

NPDR LUB RETINOPATIA PROLIFERACYJNA

Z OBRZĘKIEM PLAMKI I ZAJĘCIEM DOŁKA

Skorygowana ostrość wzroku (BCVA) $<1,0$ i błona nasiatkówkowa (ERM)

U chorych z retinopatią cukrzycową przedproliferacyjną (NPDR), zaawansowaną NDPR lub retinopatią proliferacyjną (PDR), z obrzękiem plamki (DME) i zajęciem dołka oraz skorygowaną ostrością wzroku (BCVA) < 1,0, a także obecną błoną nasiatkówkową (ERM, epiretinal membrane) zaleca się:

— terapię z zastosowaniem anty-VEGF — można oczekiwać większej liczby iniekcji w przypadku współobecności ERM - ocena skuteczności leczenia jest trudniejsza, obrzęk wycofuje się wolniej, nie należy przerywać leczenia przedwcześnie + l-: (co najmniej 6 comiesięcznych iniekcji)

— zastosowanie deksametazonu — w postaci implantu podawanego do ciała szklistego;
— klasyczną laseroterapię obwodu siatkówki i/lub ewentualnie laseroterapię ogniskową w plamce, gdy iniekcje do ciała szklistego nie pozwoliły na poprawę w zakresie morfologii i/lub funkcji siatkówki;

— PPV, gdy zdaniem lekarza ERM jest dominująca przyczyną obniżonej ostrości wzroku.

\section{Trakcje szklistkowo-siatkówkowe i/lub błona nasiatkówkowa (ERM)}

U chorych z retinopatią cukrzycową przedproliferacyjną (NPDR), zaawansowaną NDPR lub retinopatią proliferacyjną (PDR), z obrzękiem plamki (DME) i zajęciem dołka oraz trakcjami szklistkowo -siatkówkowymi i/lub obecną błoną nasiatkówkową (ERM) zaleca się:

— PPV — jeżeli trakcje biegną wertykalnie do doł$\mathrm{ka}$;

— w innym wypadku leczenie jak powyżej (wg pkt. 11).

\section{LECZENIE Z ZASTOSOWANIEM INHIBITORÓW NACZYNIOWO-ŚRÓDBŁONKOWEGO CZYNNIKA WZROSTU}

Podanie anty-VEGF $\mathrm{w}$ ramach przygotowania do PPV powinno nastąpić w okresie 5-7 dni przed planowanym zabiegiem. Należy zachować szczególną ostrożność, jeżeli PDR jest zaawansowana i widoczne są trakcje - możliwe jest pojawienie się wówczas trakcyjnego odwarstwienia siatkówki. Można rozważyć podanie połowy typowej dawki $(0,025 \mathrm{ml})$.

Leczenie anty-VEGF należy kontynuować, dopóki poprawia się morfologia siatkówki i/lub ostrość wzroku. Jeżeli osiąga się stabilizację, leczenie może zostać wstrzymane do czasu pogorszenia się morfologii siatkówki (znamienny wzrost grubości siatkówki w plamce) lub ostrości wzroku o > 5 liter na tablicy ETDRS.

Jako stabilizację należy przyjąć grubość siatkówki nie większą (w zakresie do $10-20 \mu \mathrm{m}$ ) niż podczas dwóch poprzednich wizyt (nawet gdy obrzęk jest ewidentny) oraz ostrość wzroku \pm 5 liter na tablicy ETDRS w stosunku do najlepszej osiagniętej w trakcie leczenia (lub równoważnie na tablicach Snellena). Należy jednocześnie upewnić się, czy nie występują inne zmiany w oku prowadzące do ewentualnego pogorszenia ostrości, np. progresja zaćmy. W takich wypadkach należy oprzeć się bardziej na morfologii siatkówki.

Gdy intensywne leczenie z zastosowaniem anty -VEGF nie przynosi wystarczającego efektu (przy- 
najmniej 5 comiesięcznych zalecanych dawek) należy rozważyć:

- AF (w miarę możliwości szerokokątna) i selektywną PRP;

- laseroterapię mikropulsową — jeżeli grubość siatkówki nie przekracza $400 \mu \mathrm{m}$;

— deksametazon - implant podawany do ciała szklistego;

- laseroterapię typu ogniskowego plamki w obrębie powierzchni obrzęku widocznego w OCT poza dołkiem

Jako definicję nieskuteczności przyjęto brak poprawy morfologii (grubość siatkówki bez redukcji $>10 \%$ grubości wyjściowej w dołku) i funkcji siatkówki (brak poprawy ostrości wzroku).

Zwykle należy rozważyć dodatkowe leczenie po 3 iniekcjach anty-VEGF, jeżeli brak powyższego efektu, nie zaprzestając od razu podstawowej terapii (dążąc do przynajmniej 5-6 comiesięcznych iniekcji)

\section{LECZENIE Z ZASTOSOWANIEM INIEKCJI} STEROIDÓW DO CIAŁA SZKLISTEGO

Iniekcje steroidów do ciała szklistego są leczeniem z wyboru (jako leki pierwszego rzutu), gdy:

— pacjent jest obciążony ogólnie i terapia z zastosowaniem anty-VEGF jest przeciwskazana (np. ciężka choroba wieńcowa, przebyty zawał lub udar mózgu w okresie ostatnich 6 miesięcy);

— pacjent nie ma możliwości zgłaszać się na wizyty co miesiąc;

- jako leczenie drugiego rzutu - gdy leczenie anty-VEGF pomimo stosowania zgodnie $\mathrm{z}$ charakterystyką produktu leczniczego nie okazało się skuteczne (nie powinno się tego stwierdzać przed przynajmniej 5-6 comiesięcznymi iniekcjami);

- preferowani są pacjenci po operacji zaćmy, ze sztuczną soczewką wewnątrzgałkową, jednak obecność soczewki własnej i rozwój zaćmy nie powinien być traktowany jako przeciwwskazanie do stosowania steroidów u chorych, u których nie ma przeciwskazań do operacji zaćmy. Obrzęk plamki jest poważniejszym schorzeniem niż zaćma i powinien być odpowiednio leczony, nawet gdy wiąże się to $\mathrm{z}$ narastaniem zmętnienia soczewki.

Lekiem zarejestrowanym i preferowanym jest implant deksametazonu, alternatywą jest podawanie off-label triamcinolonu, w tym wypadku częstotliwość leczenia powinna być większa i dostosowana do osiąganego efektu terapeutycznego.

\section{CZYNNIKI ROKOWNICZE}

Czynniki rokownicze u chorych z DME obejmują [29-33]:

— płyn podsiatkówkowy - lepsze rokowanie;

— większe ilości płynu śródsiatkówkowego — gorsze rokowanie;

— brak PVD - lepsze rokowanie;

- dezorganizacja wewnętrznych warstw siatkówki (DRIL, disorganization of the retinal inner layers)

- gorsze rokowanie;

— gruba naczyniówka - lepsze rokowanie;

- uprzednie leczenie z zastosowaniem anty-VEGF — bez wpływu na rokowanie.

\section{TERMINY BADAŃ OKULISTYCZNYCH W CUKRZYCY}

W cukrzycy typu 1 pierwsze badanie zalecane jest do 5 lat od czasu rozpoznania, a w cukrzycy typu 2 badanie to należy przeprowadzić bezpośrednio po rozpoznaniu choroby. Kolejne terminy badań ustala się w zależności od nasilenia retinopatii według poniższych zasad:

- retinopatia bardzo łagodna (mikroaneuryzmaty) - co 12 miesiecy;

- retinopatia łagodna (mikroaneuryzmaty, krwotoczki, wysięki) - co 12 miesięcy;

- retinopatia umiarkowana [dodatkowo kłębki waty, liczne krwotoki, anomalie naczyń żylnych, wewnątrzsiatkówkowe nieprawidłowości mikronaczyniowe (IRMA, intraretinal microvascular abnormalities) ] — co 6-12 miesięcy;

- retinopatia ciężka (duże krwotoki 4 kwadranty, przewężenie naczyń żylnych w 2 lub więcej kwadrantach, IRMA w 1 kwadrancie) co 4 miesiące (wysokie ryzyko proliferacji);

- retinopatia bardzo ciężka (2 lub więcej z objawów charakterystycznych dla postaci ciężkiej) - co 2-3 miesiące.

W niektórych szczególnych sytuacjach, np. u kobiet w ciąży, terminy badań należy wyznaczać częściej. U dzieci ze świeżo rozpoznaną cukrzycą typu 1, będących w okresie pokwitania, należy badanie siatkówki wykonać jak najszybciej.

\section{PODSUMOWANIE}

Zdaniem ekspertów stworzenie programu lekowego dla DME jest konieczne i daje szansę chorym na dostęp do optymalnego i zaplanowanego leczenia. Należy stworzyć precyzyjne kryteria włączenia do takiego programu. W programie lekowym le- 
kiem I rzutu powinien być inhibitor VEGF. Eksperci są zdania, że po 3-6 comiesięcznych iniekcjach doszklistkowych $\mathrm{z}$ anty-VEGF należy dokonać oceny efektów leczenia (ocena ostrości wzroku oraz grubości i morfologii siatkówki). Eksperci są zgodni, że należy sprecyzować, co oznacza brak odpowiedzi na leczenie anty-VEGF, oraz wyznaczyć zakresy wartości dla ocenianych parametrów. Przy braku poprawy parametrów morfologicznych i poprawy ostrości wzroku należy rozważyć inne metody leczenia, w tym wprowadzenie iniekcji doszklistkowych steroidów [z rekomendowanym implantem doszklistkowym DEX 0,7 mg (preparat Ozurdex) wg EURETINA]. Ustalenia wymagają następujące kwestie:

— które leki z grupy inhibitorów VEGF miałyby znaleźć się w programie lekowym;

— jaka jest definicja dawki wysycającej;

- jakie są wytyczne postępowania do zmiany leczenia $\mathrm{z}$ inhibitorów VEGF na terapię z zastosowaniem implantu doszklistkowego DEX 0,7 mg.

Eksperci są zdania, że w ramach programu lekowego należy umożliwić leczenie implantem DEX 0,7 mg zarówno pacjentom pseudofakijnym, jak i fakijnym. Operacja zaćmy jest zabiegiem bezpiecznym i wykonywanym powszechnie - nie można zaniedbać leczenia obrzęku plamki z powodu obaw o zmętnienie soczewki.

Ze względu na liczne dane dotyczące wzrostu IOP podczas leczenia $\mathrm{z}$ zastosowaniem implantu DEX 0,7 mg eksperci są zdania, że ciśnienie to należy regularnie monitorować. Proponowany harmonogram mierzenia IOP to: kontrola dzień po podaniu, tydzień po podaniu, 2 tygodnie po podaniu, miesiąc po podaniu, 3 miesiące po podaniu.

Ze względu na dane dotyczące rozwoju zaćmy podczas leczenia z zastosowaniem implantu doszklistkowego DEX 0,7 mg zdaniem ekspertów należy brać pod uwagę stopień zmętnienia soczewki podczas kwalifikacji do leczenia.

\section{PIŚIMIENNICTWO}

1. Raciborski F, Kłak A, Gawińska E, Figurska M. Choroby oczu — problem zdrowotny, społeczny oraz wyzwanie cywilizacyjne w obliczu starzenia się populacji.Raciborski F, Gujski M. ed. Raport Instytutu Ochrony Zdrowia, Warszawa 2016.

2. Karczewicz E, Łyszczarz B, Nojszewska E, Rejdak R, Śliwczyński A. Ocena ekonomiczna kosztów i obciążenia społecznego zaburzeń siatkówki, ze szczególnym uwzględnieniem DME i AMD.Nojszewska E. ed. Instytut Innowacyjna Gospodarka, Warszawa 2018.

3. Schmidt-Erfurth U, Garcia-Arumi J, Bandello F, et al. Guidelines for the Management of Diabetic Macular Edema by the European Society of Retina Specialists (EURETINA). Ophthalmologica. 2017; 237(4): 185-222, doi: 10.1159/000458539, indexed in Pubmed: 28423385.

4. Diabetic Retinopathy PPP. https://www.aao.org/preferred-practicepattern/diabetic-retinopathy-ppp-updated-2017.
5. Escobar-Barranco JJ, Pina-Marín B, Fernández-Bonet M. Dexamethasone Implants in Patients with Naïve or Refractory Diffuse Diabetic Macular Edema. Ophthalmologica. 2015; 233(3-4): 176-185, doi: 10.1159/000371770, indexed in Pubmed: 25661239.

6. Guigou S, Pommier S, Meyer F, et al. Efficacy and Safety of Intravitreal Dexamethasone Implant in Patients with Diabetic Macular Edema. Ophthalmologica. 2015; 233(3-4): 169-175, doi: 10.1159/000381356, indexed in Pubmed: 25924737.

7. Bonnin S, Dupas B, Sanharawi M, et al. Efficacy of Dexamethasone Intravitreal Implant for the Treatment of Diabetic Macular Edema. Eur J Ophthalmol. 2015; 25(5): 448-453, doi: 10.5301/ejo.5000581, indexed in Pubmed: 25684155.

8. Dutra Medeiros M, Postorino $M$, Navarro $R$, et al. Dexamethasone intravitreal implant for treatment of patients with persistent diabetic macular edema. Ophthalmologica. 2014; 231(3): 141-146, doi: 10.1159/000356413, indexed in Pubmed: 24356099.

9. Bansal P, Gupta V, Gupta A, et al. Efficacy of Ozurdex implant in recalcitrant diabetic macular edema - a single-center experience. Int Ophthalmol. 2016; 36(2): 207-216, doi: 10.1007/s10792-0150103-5, indexed in Pubmed: 26233578.

10. Totan $Y$, Güler $E$, Gürağaç $F B$, et al. Dexamethasone Intravitreal Implant for Chronic Diabetic Macular Edema Resistant to Intravitreal Bevacizumab Treatment. Curr Eye Res. 2016; 41(1): 107-113, doi: 1 0.3109/02713683.2014.1002048, indexed in Pubmed: 25610946.

11. Lam WC, Albiani DA, Yoganathan $P$, et al. Real-world assessment of intravitreal dexamethasone implant $(0.7 \mathrm{mg})$ in patients with macular edema: the CHROME study. Clin Ophthalmol. 2015; 9: 1255-1268, doi: 10.2147/OPTH.S80500, indexed in Pubmed: 26203215.

12. Malclès $A$, Dot $C$, Voirin $N$, et al. Real-life study in diabetic macular edema treated with dexamethasone implant: the Reldex Study. Retina. 2017; 37(4): 753-760, doi: 10.1097/IAE.0000000000001234, indexed in Pubmed: 27471826.

13. Busch C, Zur D, Fraser-Bell S, et al. International Retina Group, International Retina Group. Shall we stay, or shall we switch? Continued anti-VEGF therapy versus early switch to dexamethasone implant in refractory diabetic macular edema. Acta Diabetol. 2018; 55(8): 789-796, doi: 10.1007/s00592-018-1151-x, indexed in Pubmed: 29730822.

14. Gonzalez VH, Campbell J, Holekamp NM, et al. Early and Long-Term Responses to Anti-Vascular Endothelial Growth Factor Therapy in Diabetic Macular Edema: Analysis of Protocol I Data. Am J Ophthalmol. 2016; 172: 72-79, doi: 10.1016/j.ajo.2016.09.012, indexed in Pubmed: 27644589.

15. Khan Z, Kuriakose RK, Khan M, et al. Efficacy of the Intravitreal Sustained-Release Dexamethasone Implant for Diabetic Macular Edema Refractory to Anti-Vascular Endothelial Growth Factor Therapy: MetaAnalysis and Clinical Implications. Ophthalmic Surg Lasers Imaging Retina. 2017; 48(2): 160-166, doi: 10.3928/23258160-20170130-10, indexed in Pubmed: 28195619.

16. Kodjikian L, Bellocq D, Mathis T, et al. Pharmacological Management of Diabetic Macular Edema in Real-Life Observational Studies. Biomed Res Int. 2018(8289253), doi: 10.1155/2018/8289253, indexed in Pubmed: 30246026.

17. Aspelund T, Thornórisdóttir 0 , Olafsdottir $E$, et al. Individual risk assessment and information technology to optimise screening frequency for diabetic retinopathy. Diabetologia. 2011; 54(10): 2525-2532, doi: 10.1007/s00125-011-2257-7, indexed in Pubmed: 21792613.

18. Facts About Diabetic Eye Disease. https://nei.nih.gov/health/diabetic/retinopathy.

19. Wong TY, Sun J, Kawasaki R, et al. Guidelines on Diabetic Eye Care: The International Council of Ophthalmology Recommendations for Screening, Follow-up, Referral, and Treatment Based on Resource Settings. Ophthalmology. 2018; 125(10): 1608-1622, doi: 10.1016/j. ophtha.2018.04.007, indexed in Pubmed: 29776671Moisseiev E, Loewenstein A, Moisseiev E, et al. Diabetic Macular Edema: Emerging Strategies and Treatment Algorithms. Dev Ophthalmol. 2017; 60: 165-174, doi: 10.1159/000459706, indexed in Pubmed: 28427075.

20. Relhan N, Flynn HW, Relhan N, et al. The Early Treatment Diabetic Retinopathy Study historical review and relevance to today's management of diabetic macular edema. Curr Opin Ophthalmol. 2017; 28(3): 205-212, doi: 10.1097/ICU.0000000000000362, indexed in Pubmed: 28151747. 
21. Heier JS, Bressler NM, Avery RL, et al. American Society of Retina Specialists Anti-VEGF for Diabetic Macular Edema Comparative Effectiveness Panel, American Society of Retina Specialists Anti-VEGF for Diabetic Macular Edema Comparative Effectiveness Panel. Comparison of Aflibercept, Bevacizumab, and Ranibizumab for Treatment of Diabetic Macular Edema: Extrapolation of Data to Clinical Practice. JAMA Ophthalmol. 2016; 134(1): 95-99, doi: 10.1001/jamaophthalmol.2015.4110, indexed in Pubmed: 26512939.

22. Ishibashi T, Li X, Koh A, et al. REVEAL Study Group, REVEAL Study Group. The REVEAL Study: Ranibizumab Monotherapy or Combined with Laser versus Laser Monotherapy in Asian Patients with Diabetic Macular Edema. Ophthalmology. 2015; 122(7): 1402-1415, doi: 10.1016/j.ophtha.2015.02.006, indexed in Pubmed: 25983216.

23. Schmidt-Erfurth U, Lang GE, Holz FG, et al. RESTORE Extension Study Group, RESTORE Extension Study Group. Three-year outcomes of individualized ranibizumab treatment in patients with diabetic macular edema: the RESTORE extension study. Ophthalmology. 2014; 121(5): 1045-1053, doi: 10.1016/j.ophtha.2013.11.041, indexed in Pubmed: 24491642.

24. Hooper P, Boucher MC, Colleaux K, et al. Contemporary management of diabetic retinopathy in Canada: from guidelines to algorithm guidance. Ophthalmologica. 2014; 231(1): 2-15, doi: 10.1159/000354548, indexed in Pubmed: 24246998.

25. Zhao $Y$, Singh RP, Zhao $Y$, et al. The role of anti-vascular endothelial growth factor (anti-VEGF) in the management of proliferative diabetic retinopathy. Drugs Context. 2018; 7: 212532, doi: 10.7573/ dic.212532, indexed in Pubmed: 30181760.

26. ICO Guidelines for Diabetic Eye Care. www.icoph.org/downloads/ ICOGuidelinesforDiabeticEyeCare.pdf.
27. Nikkhah $H$, Ghazi $H$, Razzaghi MR, et al. Extended targeted retinal photocoagulation versus conventional pan-retinal photocoagulation for proliferative diabetic retinopathy in a randomized clinical trial. Int Ophthalmol. 2018; 38(1): 313-321, doi: 10.1007/s10792-017-04697, indexed in Pubmed: 28168567.

28. Weingessel B, Miháltz K, Gleiss A, et al. Treatment of Diabetic Macular Edema with Intravitreal Antivascular Endothelial Growth Factor and Prompt versus Deferred Focal Laser during Long-Term Follow-Up and Identification of Prognostic Retinal Markers. J Ophthalmol. 2018(3082560), doi: 10.1155/2018/3082560, indexed in Pubmed: 30364034.

29. Lee H, Kang KE, Chung $\mathrm{H}$, et al. Prognostic Factors for Functional and Anatomic Outcomes in Patients with Diabetic Macular Edema Treated with Dexamethasone Implant. Korean J Ophthalmol. 2018; 32(2): 116 125, doi: 10.3341/kjo.2017.0041, indexed in Pubmed: 29560616.

30. Murakami T, Suzuma K, Uji A, et al. Association between characteristics of foveal cystoid spaces and short-term responsiveness to ranibizumab for diabetic macular edema. Jpn J Ophthalmol. 2018; 62(3): 292-301, doi: 10.1007/s10384-018-0575-8, indexed in Pubmed: 29460019.

31. Koyanagi Y, Yoshida S, Kobayashi Y, et al. Visual Outcomes Based on Early Response to Anti-Vascular Endothelial Growth Factor Treatment for Diabetic Macular Edema. Ophthalmologica. 2018; 239(2-3): 94-102, doi: 10.1159/000481711, indexed in Pubmed: 29316563.

32. Sun JK, Lin MM, Lammer J, et al. Disorganization of the retinal inner layers as a predictor of visual acuity in eyes with center-involved diabetic macular edema. JAMA Ophthalmol. 2014; 132(11): 1309-1316, doi: 10.1001/jamaophthalmol.2014.2350, indexed in Pubmed: 25058813. 